\title{
En mann i 50-årene med høyt ferritinnivå og økende kognitiv svikt
}

\author{
En frisk mann fikk i slutten av 30-årene påvist forhøyet ferritinnivå, noe \\ som ga mistanke om hemokromatose. Han ble i mange år behandlet \\ med årelating. I 50-årsalderen fikk han progredierende nevropsykiat- \\ riske symptomer. En blodprøve ga den endelige diagnosen - mer enn \\ 20 år etter første tegn på sykdom.
}

Ifølge journalen var pasienten $i$ slutten av 30-årene da han tilfeldig fikk påvist et forhøyet s-ferritinnivå på rundt $800 \mu \mathrm{g} / \mathrm{l}$ $(34-300 \mu \mathrm{g} / \mathrm{ll})$, transferrinmetning $11-16 \%$ (20-45\%), s-ALAT $90 \mathrm{U} / \mathrm{l}(10-50 \mathrm{U} / \mathrm{l})$ og hemoglobinnivå $12,8 \mathrm{~g} / 100 \mathrm{ml}(13,4-17,0 \mathrm{~g} /$ $100 \mathrm{ml}$. Han hadde vært blodgiver og gitt blod sju ganger, men måtte slutte på grunn av en tendens til lavt hemoglobinnivå. Bortsett fra økt tretthet var han frisk og i full jobb.

Han ble henvist til hematologisk poliklinikk. Den lave transferrinmetningen talte imot hemokromatose. Man mente derfor at leversykdom med sekundær hyperferritinemi var en mer sannsynlig årsak.

S-ferritin er en vanlig analyse i allmennpraksis, og moderat hyperferritinemi er et relativt hyppig funn (1). Forbigående økning ses ved akutt inflammatorisk sykdom med økt syntese av ferritin og andre akuttfaseproteiner, og ved tilstander som gir levercelleskade med lekkasje av ferritin, sælig hepatitt og sporadisk overdrevet inntak av alkohol (2). Varig hyperferritinemi ses ved kroniske tilstander som alkoholisme, infeksjon, inflammatorisk sykdom, fettlever, diabetes, enkelte kreftsykdommer, hemolyse og jernoverskudd på grunn av arvelig hemokromatose $(1,3)$.

Hos en frisk mann i 30-40-årsalderen gir et stabilt forhøyet ferritinnivå over 500-600 $\mu \mathrm{g} / 1$ mistanke om arvelig hemokromatose i preklinisk fase. Lett forhøyet s-ALAT og tretthet, som hos vår pasient, er vanlige innledende symptomer ved overgang til klinisk stadium. Lav transferrinmetning stemte imidlertid ikke med denne diagnosen, ettersom forhøyet transferrinmetning, over $45 \%$, er et patognomonisk funn ved arvelig hemokromatose (4).

Pasienten ble fulgt opp ved hematologisk poliklinikk. Sykdomsårsaken forble ukjent, men man mente at han hadde jernoverskudd, og det ble forsøkt behandling med årelating etter samme opplegg som ved hemokromatose. Som ventet falt s-ferritinverdien, s-ALAT og transferrinmetningen. På grunn av tendensen til lavt hemoglobinnivå, med fare for utvikling av anemi, ble intervallet mellom årelatingene forlenget. I behandlingsfrie perioder økte s-ferritinnivået, med forbedring av hematologisk status.

Hyperferritinemien ble vurdert som uttrykk for et patogenetisk jernoverskudd som kunne fjernes ved hjelp av årelating. Årelating stimulerer erytropoesen for å erstatte blodtapet (4). Økt hemoglobinsyntese øker jernbehovet i margen, og så lenge det finnes tilgjengelig mobiliserbart jern unngås anemi. Hos vår pasient, der årelating førte til anemiutvikling, ble målet for behandlingen endret fra å fjerne hele til å begrense jernoverskuddet.

I journalen beskrives at da pasienten var $i$ 50-årene, hadde han fått insulinavhengig diabetes, tåkesyn på grunn av mild ikke-proliferativ retinopati og svekket hukommelse, som påvirket dagliglivet. Han var fortsatt $i$ arbeid. I de foregående fire år var det utført årelating omtrent hver 4. måned.

Ferritinnivået var 400-500 $\mu \mathrm{g} / \mathrm{l}, \mathrm{s}-A L A T$ 70-80 U/l, transferrinmetningen $<20 \%$ og løselig transferrinreseptor $i$ serum (s-TfR) var økt til 2,1 mg/l (0,8-1,5 mg/l). Leverbiopsi viste moderat steatose, fibrose og rikelig jernavleiring $i$ hepatocyttene, men ikke i kupffercellene. Gentesting, som nylig var blitt tilgjengelig, viste ikke mutasjon $i$ hemokromatosegenet HFE, som er hyppigste årsak til arvelig hemokromatose.

Pasienten hadde en jernavleiringssykdom med et laboratoriemønster som utelukket «klassisk hemokromatose». Den liknet mer på en annen arvelig hemokromatosevariant, type 4, som nylig var beskrevet i litteraturen og ble kalt ferroportinsykdom (5).

Normal HFE-genstatus, lav transferrinmetning, funksjonell jernmangel med økt s-TfR, tendens til hypokrom anemi og redusert toleranse for årelating på tross av jernavleiring i lever og hyperferritinemi er ho-

\author{
Marte-Helene Bjørk \\ marte.bjork@uib.no \\ Nevrologisk avdeling \\ Haukeland universitetssykehus \\ og \\ Klinisk institutt 1 \\ Universitetet i Bergen \\ Ivar Otto Gjerde \\ Nevrologisk avdeling \\ Haukeland universitetssykehus \\ Charalampos Tzoulis \\ Nevrologisk avdeling \\ Haukeland universitetssykehus \\ og \\ Klinisk institutt 1 \\ Universitetet i Bergen

\section{Rune Johan Ulvik} \\ Klinisk institutt 2 \\ Universitetet i Bergen \\ og \\ Hematologisk seksjon \\ Medisinsk avdeling \\ og \\ Laboratorium for klinisk biokjemi \\ Haukeland universitetssykehus

\section{Laurence Albert Bindoff} \\ Nevrologisk avdeling \\ Haukeland universitetssykehus \\ og \\ Klinisk institutt 1 \\ Universitetet i Bergen
}

Engelsk oversettelse på www.tidsskriftet.no 


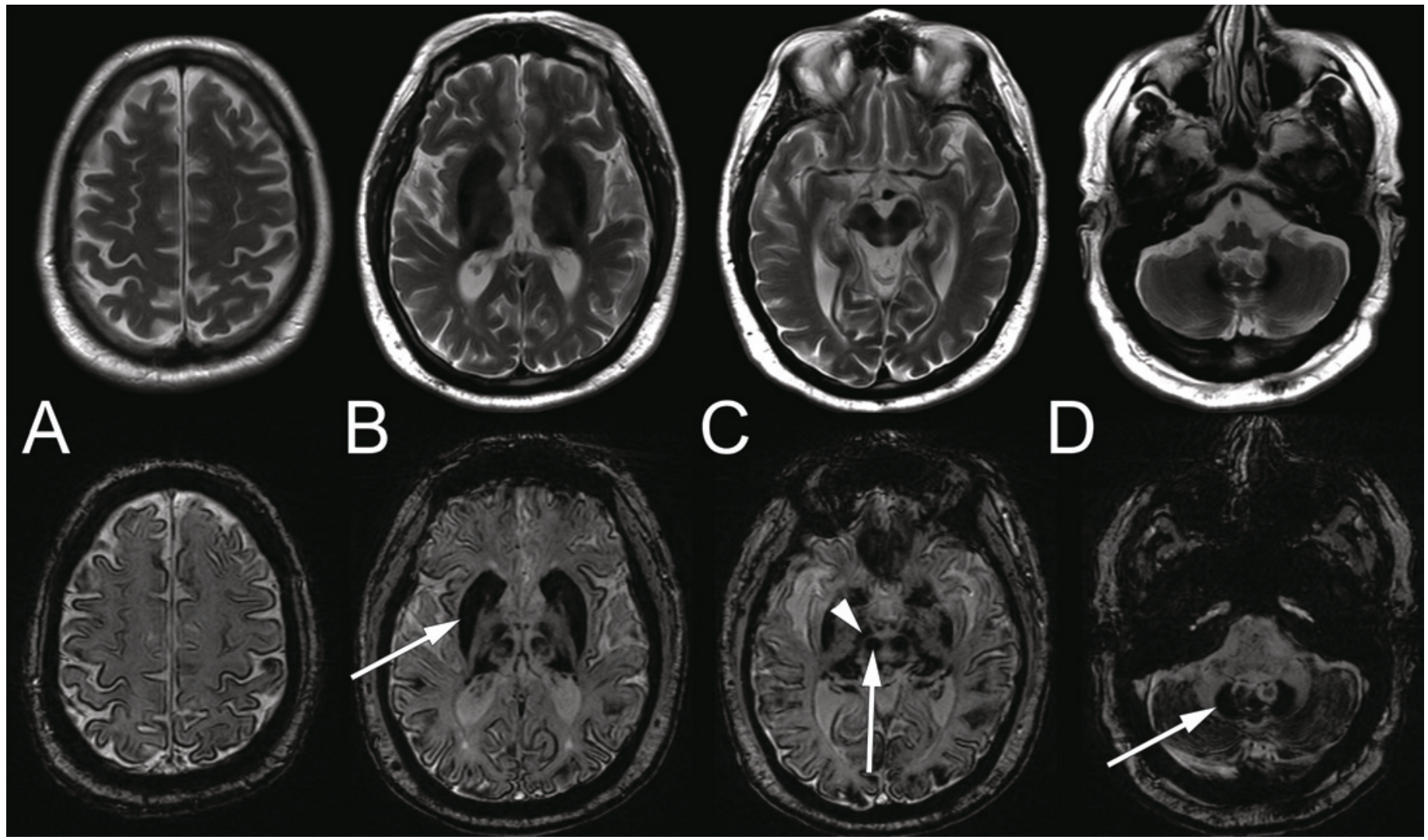

Figur 1 Cerebral MR av pasienten da han var i slutten av 50-årene. T2-vektede (øvre rad) og susceptibilitetsvektede (SWI, nedre rad) serier. SWI er betydelig mer sensitiv for jernavleiring enn T2-serien. Det foreligger utbredt og symmetrisk jernavleiring. Jernavleiringen viser seg som lavsignal icerebral (A) og cerebellar cortex (D), striatum (pil i B), nucleus ruber og substantia nigra (pil og pilhode i C) og nucleus dentatus i lillehjernen (pil i D)

vedfunn ved arvelig autosomalt dominant ferroportinsykdom (5). Dette stemte godt med vår pasient. Men leverbiopsien, som var negativ for jernavleiring i kupffercellene, og det kliniske bildet, med diabetes, retinopati og kognitiv svikt, passet ikke.

Da han var i 50 -årsalderen, ble han innlagt i nevrologisk avdeling på grunn av forbigående symptomer som ble tolket som et lite hjerneinfarkt i bakre kretsløp, ifølge journalen. T2vektede MR-bilder av hodet viste uttalte lavsignalforandringer i basalganglier og nucleus dentatus $i$ lillehjernen. MR-angiografi var normal. I bildebeskrivelsen er lavsignalforandringene tolket som sentrale jernavleiringer i hjernen.

I de påfølgende år fikk pasienten økende kognitiv svikt og endret personlighet, med $ø$ kende aggresjon. Han sluttet $i$ arbeid. Fastlegen henviste ham til poliklinisk utredning $i$ en alderspsykiatrisk avdeling. Ifølge journalen viste elektroencefalografi (EEG) uspesifikk frontotemporal dysfunksjon, forenlig med lett encefalopati. MR-undersøkelse (DWI- og SWI-sekvenser) av hodet viste generaliserte jernavleiringer både i store- og lillehjernen. Da han var i slutten av 50 -årene, ble han innlagt $i$ avdelingen for utredning av demens.
Fluordeoksyglukosepositronemisjontomografi (FDG-PET) av hjernen viste uspesifikke patologiske forandringer. Det ble også utført MR abdomen, som viste moderat jernavleiring i leveren og atrofi med betydelig fettinfiltrasjon $i$ pancreas. Pasienten ble utskrevet med diagnosen uspesifisert moderat demens med frontalt syndrom og henvist til nevrologisk avdeling for videre utredning av sykdomsårsaken.

Nevrologisk undersøkelse viste ustø gange, ataktisk kne-hæl-prøve, feilpeking ved finger-nese-prøve, intensjonstremor og langsomme øyesakkader, som kunne tyde på sykdom i lillehjernen. MR av hodet viste utbredte jernavleiringer i cerebral cortex, hjernestammekjerner og basalganglier (fig 1), men ikke i hjernehinnene. Spinalvæsken var normal, bortsett fra lett forhøyet totalprotein. Demensmarkørene viste uspesifikt forhøyet tauprotein og normalt $\beta$-amyl.

Pasienten hadde jernavleiring sentralt hjernen, med progredierende nevrologiske symptomer og funn fra flere sentralnervøse systemer, inkludert retina. Nevrologiske symptomer kombinert med jernopphopning i hjerne og andre organer finnes ved flere ulike progredierende tilstander kalt «neuro- degeneration with brain iron accumulation» (NBIA) $(6,7)$. Ved disse tilstandene akkumuleres det jern i hjernen, spesielt i basalgangliene. Dette ses best på T2-vektede og susceptibilitetsvektede MR-bilder (SWI). dert:

Nevroferritinopati gir jernavleiring i basalgangliene, men s-ferritinnivået er ofte lavt. Sykdommen kan gi parkinsonisme, men likner fenotypisk mer på Huntingtons sykdom (6).

Superficiell siderose gir jernavleiring på grunn av nedbrytning av hemoglobin i spinalvæsken. Årsaken er ofte kronisk blødning i subaraknoidalrommet. Vanlige symptomer er nevrogent hørselstap, ataksi, pyramidale funn og demens. Vår pasient hadde ikke jernavleiring i hjernehinnene og ikke kjent blødningsfokus.

Wilsons sykdom er en genetisk lidelse som gir kobberavleiring i hjerne, lever og hornhinner, med utvikling av levercirrhose, nevropsykiatriske symptomer, bevegelsesforstyrrelser og hemolytisk anemi (8). Et patognomonisk tegn er Kayser-Fleischerring i cornea. Sykdommen kjennetegnes av lavt s-kobber og s-ceruloplasmin og høyt innhold av kobber i urin. Imidlertid var ver- 
ken leverbiopsien, øyestatus eller metallavleiringene typisk for Wilsons sykdom.

En annen jernavleiringssykdom med lavt s-kobber og s-ceruloplasmin er aceruloplasminemi (6).

På mistanke om denne tilstanden ble det rekvirert s-kobber og s-ceruloplasmin. Ingen av prøvene var målbare: s-kobber $<2,0 \mu \mathrm{mol} / \mathrm{l}(13-21 \mu \mathrm{mol} / \mathrm{l})$ og s-ceruloplasmin < 0,04 g/l (0,22-0,38 g/l). På bakgrunn av typiske kliniske, bildediagnostiske og biokjemiske funn ble diagnosen aceruloplasminemi stilt.

På diagnosetidspunktet var mannen blitt nesten 60 år. Han hadde betydelig jernavleiring $i$ hjernen og var preget av kognitiv svikt, demens, kronisk tretthet og nevrologiske symptomer forenlig med skade av lillehjernen, som koordinerings- og gangvansker, dysartri, intensjonstremor og dysdiadokokinesi.

Behandling med et medikament som binder og utskiller jern i urinen, en såkalt kelator, er eneste mulighet til å begrense sykdommen. Desferrioxamin og de nyere perorale kelatorene deferasirox og deferipron har vært prøvd hos enkelte pasienter med aceruloplasminemi og andre NBIA-tilstander. Så langt er effekten usikker (9-11). Vi planlegger å starte behandling med en peroral kelator kombinert med forsiktig årelating.

\section{Diskusjon}

Kasuistikken viser forløp og klinisk presentasjon hos en mann med den sjeldne sykdommen aceruloplasminemi hvor det gikk 20 år før diagnosen ble stilt. Det tidligste og viktigste funnet var stabil hyperferritinemi uten alvorlige kliniske symptomer, noe som ikke uventet ga mistanke om arvelig hemokromatose. Transferrinmetningen var imidlertid lav, noe som talte imot denne diagnosen. Ved klassisk hemokromatose er transferrinmetningen typisk over øvre referansegrense $(45 \%)(4)$. Det var heller ikke mulig å utdype diagnostikken ved hjelp av genanalyse, da dette var flere år før oppdagelsen i 1996 av hemokromatosegenet $H F E$ og mutasjonen $C 282 Y$, som opptrer hos $85 \%$ av pasientene med klassisk arvelig hemokromatose (12). Behandling med årelating ble iverksatt fordi man mente at pasienten hadde et patogenetisk jernoverskudd av ukjent årsak.

Etter flere års oppfølging av pasienten og i lys av ny kunnskap om genetisk regulering av jernstoffskiftet ble det klart at sykdommen kunne skyldes en annen nyoppdaget genmutasjon. I dag vet vi at sjeldne mutasjoner i flere andre jernregulerende gener kan forårsake ikke- $H F E$ arvelig hemokromatose av varierende laboratoriemessig og klinisk fenotype (13).

Den nest hyppigste varianten etter $H F E$ - hemokromatose er ferroportinsykdom, som skyldes en sjelden autosomalt dominant mutasjon i genet som koder for proteinet ferroportin (5). Dette er et cellemembranprotein som transporterer jern ut av cellene. Genmutasjonen blokkerer den cellulære eksporten av jern, som dermed holdes tilbake i jernlageret, med sekundær økning av s-ferritin. Dette rammer særlig makrofagene, som normalt skiller ut store mengder jern til plasma fra nedbrytning av utdaterte erytrocytter. Resultatet er nedsatt jerntilførsel til plasma, med nedsatt transferrinmetning og mild hypokrom anemi. Årelating forsterker tendensen til anemi fordi det ikke mobiliseres nok jern fra makrofagene til å dekke behovet ved økt hemoglobinsyntese. Med tiden deponeres det også store mengder jern i hepatocyttene, noe som gir utvikling av leverskade.

Pasienten hadde et laboratoriemønster og enkelte symptomer som minnet om den nylig påviste ferroportinsykdommen - med ett viktig unntak: Leverbiopsi viste ikke jernavleiring i makrofagene (kupffercellene), som er et patognomonisk funn (5). Analyse av mutasjon(er) i ferroportingenet var heller ikke tilgjengelig. Først da pasienten til slutt var blitt alvorlig syk med nevropsykiatriske symptomer og MR-funn i hjernen som verken kunne forklares av HFEhemokromatose eller ferroportinsykdom, ble den riktige diagnosen stilt ved hjelp av en enkel blodprøve.

Aceruloplasminemi er en autosomalt recessiv tilstand med mangel på ceruloplasmin grunnet en mutasjon i ceruloplasmingenet ( 6 , 14). Ceruloplasmin er et kobberbindende plasmaprotein som oksiderer jern før det kan bindes til transferrin og transporteres til erytropoetisk marg og andre kroppsvev. I likhet med ferroportinsykdom fører mutasjon i ceruloplasmingenet til nedsatt utskilling av jern fra cellene, med opptil 40 ganger økning av s-ferritin, lav transferrinmetning, tendens til anemi og intoleranse for intensiv årelating (15).

Sykdommen kjennetegnes av sterkt nedsatt eller ikke påvisbart ceruloplasmin og kobber i serum og progredierende jernavleiring i sentralnervesystem, lever og pancreas, med langsom nevrodegenerasjon, inkludert degenerasjon av retina, leverfibrose og insulinkrevende diabetes. Hypometabolisme kan ses i basalgangliene og thalamus ved hjelp av FDG-PET, og atrofi av lillehjernen er vanlig. Årsaken til cerebral jernavleiring $\mathrm{i}$ basalgangliene, thalamus, nukleus dentatus og cortex er ukjent. Ved obduksjon er det også funnet jernavleiring i hjertet, skjoldkjertelen, nyrene og milten (14).

Kliniske symptomer opptrer fra 30-40 års alder og forverres langsomt med årene. I en metastudie, som inkluderte 28 homozygote pasienter med gjennomsnittsalder 51 år, var de vanligste nevropsykiatriske symptomene cerebellar ataksi (46\%), kognitiv svikt (42\%) og dyskinesier i ansiktet (28\%) (15). Heterozygote bærere kan ha moderate endringer i laboratorieprøvene, uten eller med mild sykdom.

Aceruloplasminemi ble beskrevet første gang i Japan i 1987 (16). Tilstanden er meget sjelden, med en beregnet prevalens i Japan på én per to millioner innbyggere (15). Prevalensen i andre land er ukjent. Det er beskrevet mer enn 40 ulike mutasjoner (16). Hvilken genmutasjon(er) som finnes hos vår pasient, er ukjent. Vi anser likevel diagnosen aceruloplasminemi som sikker, på bakgrunn av ceruloplasmin- og kobbermangel i serum assosiert med endringene i jernstatus, typiske MR-funn i hjernen og det kliniske uttrykket med typiske nevrologiske symptomer, demens og diabetes.

Forsiktig årelating fjerner jern fra hepatocyttene, med fall i s-ferritin, men ikke fra hjernen, hvor det eneste alternativet er behandling med jernbindende kelator. På grunn av lav forekomst av NBIA-sykdommer vet vi imidlertid lite om effekten av kelatorbehandling. Noen få observasjonsstudier og kasuistikker har vist at kelator fjerner jern fra hepatocyttene, men har liten og varierende effekt på hjernen, hvor ulike faktorer som penetrans av blod-hjerne-barrieren, sykdomsstadium og type genmutasjon kan ha betydning for resultatet $(9-11,17)$. I lys av den dårlige prognosen er det viktig at pasienter med aceruloplasminemi og andre NBIAsykdommer identifiseres tidlig, slik at man kan vurdere å starte forebyggende kelatorbehandling. Kombinasjonen av hyperferritinemi og nevrologiske symptomer bør utredes med s-ceruloplasmin, s-kobber, leverprøver, glukosetoleransetest, øyeundersøkelse samt MR av hodet med tanke på cerebral jernavleiring. Symptomtriaden kognitiv svikt, bevegelsesforstyrrelser og retinopati bør særlig gi mistanke om aceruloplasminemi, som er lett å bekrefte eller utelukke ved hjelp av enkle blodprøver. Gevinsten for pasienter der tilstanden oppdages tidlig, kan være stor.

Pasienten har gitt samtykke til at artikkelen blir publisert

\section{Marte Helene Bjørk (f. 1980)}

er ph.d. i nevrovitenskap, lege i spesialisering og postdoktor

Forfatter har fylt ut ICMJE-skjemaet og oppgir ingen interessekonflikter.

\section{Ivar Otto Gjerde (f. 1947)}

er spesialist i klinisk nevrofysiologi og i nevrologi.

Forfatter har fylt ut ICMJE-skjemaet og oppgir ingen interessekonflikter. 


\section{Charalampos Tzoulis (f. 1979)}

er ph.d. og spesialist i nevrologi, med spesiell interesse for nevrogenetikk og bevegelsesforstyrrelser. Han er leder av forskningsgruppen Translational Science in Neurodegeneration and Aging.

Forfatter har fylt ut ICMJE-skjemaet og oppgir ingen interessekonflikter.

\section{Rune J. Ulvik (f. 1947)}

er spesialist i klinisk kjemi, overlege og professor.

Forfatter har fylt ut ICMJE-skjemaet og oppgir ingen interessekonflikter.

\section{Laurence Albert Bindoff (f. 1951)}

er spesialist i nevrologi og professor.

Forfatter har fylt ut ICMJE-skjemaet og oppgir ingen interessekonflikter.

\section{Litteratur}

1. Ellervik C Marott JL, Tybjærg-Hansen A et al. Total and cause-specific mortality by moderately and markedly increased ferritin concentrations: general population study and metaanalysis. Clin Chem 2014; 60: 1419-28.

2. Weiss $\mathrm{G}$. Modification of iron regulation by the inflammatory response. Best Pract Res Clin Haematol 2005; 18: 183-201

3. Adams PC, Barton JC. A diagnostic approach to hyperferritinemia with a non-elevated transferrin saturation. J Hepatol 2011; 55: 453-8.

4. Bacon BR, Adams PC, Kowdley KV et al. Diagnosis and management of hemochromatosis: 2011 practice guideline by the American Association for the Study of Liver Diseases. Hepatology 2011: 54 : 328-43.

5. Pietrangelo $A$. The ferroportin disease. Blood Cells Mol Dis 2004; 32: $131-8$

6. Schneider SA, Hardy J, Bhatia KP. Syndromes of neurodegeneration with brain iron accumulation (NBIA): an update on clinical presentations, histological and genetic underpinnings, and treatment considerations. Mov Disord 2012; 27: 42-53.

7. Hogarth P. Neurodegeneration with brain iron accumulation: diagnosis and management. J Mov Disord 2015; 8: 1-13.

8. Ala A, Walker AP, Ashkan K et al. Wilson's disease. Lancet 2007; 369: 397-408.

9. Pan $\mathrm{PL}$, Tang $\mathrm{HH}$, Chen $\mathrm{Q}$ et al. Desferrioxamine treatment of aceruloplasminemia: Long-term follow-up. Mov Disord 2011; 26: 2142-4.

10. Finkenstedt A, Wolf E, Höfner E et al. Hepatic but not brain iron is rapidly chelated by deferasirox in aceruloplasminemia due to a novel gene mutation. J Hepatol 2010; 53: $1101-7$.
11. Abbruzzese G, Cossu G, Balocco M et al. A pilot trial of deferiprone for neurodegeneration with brain iron accumulation. Haematologica 2011: 96: 1708-11

12. Feder JN, Gnirke A, Thomas W et al. A novel MHC class I-like gene is mutated in patients with hereditary haemochromatosis. Nat Genet 1996: 13: 399-408

13. Camaschella C, Poggiali E. Rare types of genetic hemochromatosis. Acta Haematol 2009; 122: 140-5.

14. Yoshida K, Furihata K, Takeda S et al. A mutation in the ceruloplasmin gene is associated with systemic hemosiderosis in humans. Nat Genet 1995; 9: $267-72$

15. McNeill A, Pandolfo M, Kuhn J et al. The neurological presentation of ceruloplasmin gene mutations. Eur Neurol 2008; 60: 200-5.

16. Kono S. Aceruloplasminemia. Curr Drug Targets 2012; 13: 1190-9.

17. Tai M, Matsuhashi N, Ichii 0 et al. Case of presymptomatic aceruloplasminemia treated with deferasirox. Hepatol Res 2014: 44: 1253-8.

Mottatt 11.9. 2014, første revisjon innsendt 4.2. 2015, godkjent 20.5. 2015. Redaktør: Lise Mørkved Helsingen. 